\title{
On mechanical properties and bioactivity of PVDF-BCP composites
}

\section{(Propriedades mecânicas e bioativas do compósito PVDF-BCP)}

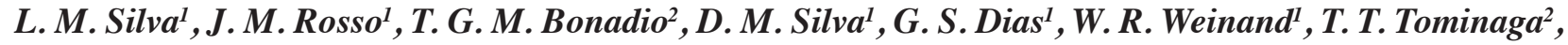

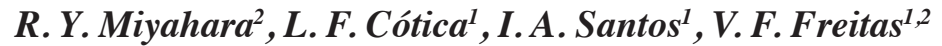 \\ ${ }^{I}$ State University of Maringá, Department of Physics, Maringá, PR, Brazil \\ ${ }^{2}$ State University of Midwest (Unicentro), Department of Physics, Guarapuava, PR, Brazil
}

\begin{abstract}
A ceramic/polymer biocomposite with high potential for multifunctional practical applications in bone tissue engineering was synthesized by using a well-known piezoelectric polymer, polyvinylidene fluoride (PVDF), and a high bioactive biphasic calcium phosphate (BCP) ceramic obtained from recycled fish bones. High-bioactivity was observed for the PVDF-BCP composite when it was subjected to conditions that simulate the animal body once a very thick apatite layer $(9 \mu \mathrm{m})$ was grown on its surface in an immersion experiment (7 days) in simulated body fluid. The structural characteristics of the PVDF-BCP composite showed similarities with highly bioactive young animal bones, overlapped with PVDF polymorphic phases. Mechanical tests revealed properties very similar to those of the human bone tissue with a resistance strength reaching $80 \mathrm{MPa}$. Together, all these factors indicated a very promising material for application in osseous implants/replacement with postoperative recovery controlled/ accelerated by external stimuli.
\end{abstract}

Keywords: biocomposites, PVDF, hydroxyapatite, bioactivity, biomaterials.

\section{Resumo}

Um biocompósito cerâmico/polimérico com alto potencial para aplicações práticas multifuncionais em engenharia de tecidos ósseos foi sintetizado usando o conhecido polímero piezoelétrico, fluoreto de polivinilideno (PVDF), e a cerâmica altamente bioativa, fosfato de cálcio bifásica (BCP), obtida a partir de ossos de peixes reciclados. Uma alta bioatividade foi observada no compósito PVDF-BCP quando este foi submetido a condições que simulam um corpo animal. De fato, uma camada de apatita muito espessa $(9 \mu \mathrm{m})$ cresceu em sua superfície no experimento de imersão (7 dias) em fluido corpóreo simulado (SBF). As características estruturais do compósito PVDF-BCP mostraram semelhanças com ossos de animais jovens, altamente bioativos, sobrepostos com fases polimórficas de PVDF. Ensaios mecânicos revelaram propriedades muito semelhantes às do tecido ósseo humano, com uma resistência à compressão atingindo $80 \mathrm{MPa}$. Juntos, todos esses fatores indicaram um material muito promissor para aplicação em implantes elou substituições ósseas com recuperação pós-operatória controladalacelerada por estímulos externos.

Palavras-chave: biocompósitos, PVDF, hidroxiapatita, bioatividade, biomateriais.

\section{INTRODUCTION}

In the current research scenario of orthopedics and traumatology, the study of biomaterials has been intensified due to the development of new and improved medical treatment protocols that are directly correlated or dependent of the performance of these materials [1]. For instance, their biocompatibility needs to be adequate because if these materials are inserted in an animal body they must not cause or stimulate any allergic or inflammatory reaction [1]. In fact, bioactivity, easy absorption/integration by the human body and osseointegration, which is defined as the ability of the material to bind chemically to the bone by means of calcium phosphate formation, or apatite formation $\left[\mathrm{Ca}_{5-\mathrm{n}}\left(\mathrm{PO}_{4}\right)_{3}(\mathrm{OH}, \mathrm{F}, \mathrm{Cl})\right.$ - also called calcium deficient hydroxyapatite] [2], are key requirements for potentially applicable biomaterials [1]. Among them, the so-called bioactive materials, which have the ability to bind or adhere to living tissues, have also attracted great interest [2]. Furthermore, advanced materials, as the multifunctional ones, have been pointed to drive the progress in this area because possess two or more properties or functionalities that can be used simultaneously or individually in the same device [1-4]. Bioactive calcium phosphates, and specifically the hydroxyapatite $\left[\mathrm{HA}-\mathrm{Ca}_{10}\left(\mathrm{PO}_{4}\right)_{6}(\mathrm{OH})_{2}\right]$ that is one of their most interesting variations whose chemical, physical and mechanical characteristics are very close to the mineral phase of the human bone [3], find large usability in medicine and dentistry, notably in bone implants, reconstruction and/ or replacement of bone tissues [4]. In fact, the use of HA has grown constantly due to the improved quality of life provided by its application in partial or full replacement of fractured bones [1]. Moreover, HA-based ceramics tend to show special characteristics that are very similar to those of the animal bone as osteoconduction [5], for instance, which is the process related to the bone growth on a surface 
$[6,7]$. These characteristics have been associated to the similar structure and chemical bonds usually found in mineral bone matrices and HA [8-11]. Recently, a specific HA was obtained by an environmental friendly process which consists in the extraction of hydroxyapatite from the recyclable fish bones [12]. This specific hydroxyapatite has an interesting structural biphasic formation hereinafter named as biphasic calcium phosphate (BCP), where $\mathrm{BCP}=\mathrm{HA}+\beta-\mathrm{TCP}$ [tricalcium phosphate in the $\beta$ phase $\left.\mathrm{Ca}_{3}\left(\mathrm{PO}_{4}\right)_{2}\right]$, and shows elevated bioactivity and rapid natural absorption by the animal body $[13,14]$ due to the similarities between its properties and those of young osseous tissues. Interestingly, previous studies have also shown that BCP can be modified to achieve different mechanical configurations by controlling its porosity as a scaffold controlling [15]. These studies also showed that $\mathrm{BCP}$ is more bioactive than pure HA or TCP [16]. In this way, BCP emerges by showing a huge potential to practical applications in human bone substitution and can be combined with other materials to become a multifunctional material [17].

Composite materials naturally emerge as potential candidates for advanced applications due to the possibility of integrating two or more properties from different materials in a single component or device [18]. For instance, a bioactive and a piezoelectric biocompatible material can be combined in a biocomposite to accelerate the bone calcification in the fracture healing process, whereas applied external oscillating electrical fields can activate the piezoelectric response, reorganizing the electric charges on the biocomposite surface and accelerating the bone healing [19]. In this process, the direction of the surface induced electric dipoles $(\overrightarrow{\mathrm{P}})$ can be changed by using an external oscillating electric field $(\overrightarrow{\mathrm{E}})$, as schematically shown in Fig. 1. This arrangement promotes a constant ionic exchange between the biomaterial surface and the osteoinductive medium or animal body, inducing and accelerating the formation of an HA layer, catalyzing the curing process. In the last years many studies with electrically polarized hydroxyapatite (HA) [20], $\mathrm{BaTiO}_{3}(\mathrm{BT})$ [21], polyvinylidene fluoride (PVDF) [22], hydroxyapatitebarium titanate (HABT) [23], and poly(vinylidenefluorideco-trifluoroethylene)-barium titanate [P(VDF-TrFE)$\mathrm{BaTiO}_{3}$ ] [24] composites were conducted in in vitro and in vivo experiments. The obtained results indicated a higher bioactivity for ceramics and polarized composites in comparison with non-polarized ones. Furthermore, high segregation/adsorption and formation of bone cells were observed in the negative surface of electrically polarized samples. In fact, polarized samples can be obtained when piezoelectric/ferroelectric materials are exposed to static external electrical fields. In this process, the internal dipoles/ domains are oriented along the field direction, and one of the surfaces of the polarized material become negatively charged, while the other acquires a positive charge. In this way, considering previous reports where the influence of the electric charge surface on the activity of biomaterials [25] was pointed out and discussed, it is ease to intuit that piezoelectric materials can be used to catalyze biological responses. Recent studies have been conducted in order to understand the potentialities of the polyvinylidene fluoride $\left[\left(\mathrm{C}_{2} \mathrm{H}_{2} \mathrm{~F}_{2}\right)_{\mathrm{n}}\right.$ or PVDF] matrix composites in human implants [26-32]. In this way, different biological applications have been thought for PVDF polymer, leading to different synthesis technique and sample architectures, as scaffold, for example [27]. In fact, studies conducted in cell culture have indicated some advantageous aspect of PVDF polymer for animal implants. These results indicated high proliferation of the osteoblast cells, which are bone cells, in PVDF films [28], and more bioactivity in the polar PVDF phase ( $\beta$-PVDF) and poled PVDF films, mainly under mechanical stimuli $[29,30]$. Currently, a novel generation of highly advanced PVDF-based implants has been thought and developed, as those where PVDF-based nanogenerators, that were successfully implanted/tested in rats [31], attested the applicability of PVDF for bio-applications. Furthermore, a PVDF-HA composite was also developed as an osseous implant [32].

It seems clear that new multifunctional biomaterials must show a bioactivity influenced by another property, which should be externally controlled. In addition, these biomaterials must have specific properties (mechanical, thermal, electrical, etc.) that fit the needs of human body implants. In this context, interesting requirements for biocompatible composites, as adjustable mechanical, thermal and possibly piezoelectric properties, can be fitted by PVDF-BCP composites. In fact, PVDF can exhibit four crystalline phases $(\alpha, \beta, \gamma$ and $\delta)$ that can be differentiated by the $\mathrm{C}-\mathrm{C}$ bond conformation along its main polymeric chain and by their piezoactivity [33]. The polar $\beta$-phase is the most interesting for practical applications once it shows very intense piezoelectric and pyroelectric responses [34]. Furthermore, the amounts of crystalline phase and the percentage of the $\beta$-phase can be tuned by adequate protocols of samples processing. On the other hand, BCP is a highly bioactive material with mechanical properties very different (it is stronger and harder) from that of

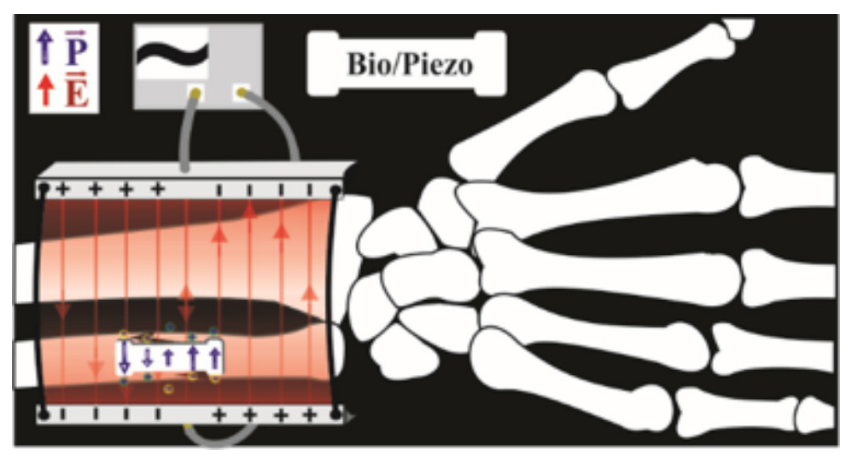

Figure 1: Schematic representation of a possible post-trauma treatment with the excitation of an external electric field $(\overrightarrow{\mathrm{E}})$ in a bioactive/piezoelectric composite to accelerate a fracture healing process by the oscillation of the electric dipoles $(\overrightarrow{\mathrm{P}})$.

[Figura 1: Representação esquemática de um possível tratamento pós-trauma com a excitação de um campo elétrico externo $(\vec{E})$ em um composto bioativo/piezoelétrico para acelerar um processo de cicatrização pela oscilação dos dipolos elétricos $(\vec{P})$.] 
PVDF. Thus, a possible mixing of the BCP ceramic with PVDF polymer can result in an interesting multifunctional bioactive composite that can be used in a vast range of novel biomedical applications. In fact, different structural and physical (mechanical, thermal, electrical, etc.) properties can be achieved in these composites by simply adjusting/ tuning the PVDF and $\mathrm{BCP}$ concentrations, leading to different materials that can be used in different parts of the body. However, for reaching the desired applications a long way still needs to be covered and basic characterization on synthesis processes and bioactivity responses must be developed. In this work, a PVDF-BCP composite was synthesized in order to obtain a multifunctional bioactive material for replacement of animal osseous tissues. Its structural, microstructural and mechanical properties, as well its bioactivity, were investigated and the combined results indicate that this composite can be adequately used for implants in different areas of the human body. In fact, the structural investigations revealed the formation of a biphasic composite material formed by the PVDF polymer, $\alpha$ and $\beta$ phases, and the BCP ceramic, $\mathrm{HA}+\beta-\mathrm{TCP}$, whose structure favors biocompatibility. The mechanical properties of the PVDF-BCP composite were found very close to those of the human bone tissue and the scanning electron microscopy images revealed that a very thick HA layer was grown on the composite surface in the SBF experiment, attesting the high-bioactivity of the PVDF-BCP composite.

\section{MATERIALS AND METHODS}

The 60\%PVDF-40\%BCP (PVDF-BCP) composite was prepared by a conventional powder mixture protocol (mass - wt\%), starting from synthetic PVDF powder (Alfa-Aesar $99.8 \%$, melting point 155 to $170{ }^{\circ} \mathrm{C}$, density $1,78 \mathrm{~g} / \mathrm{mL}$ ) and BCP (90\% HA-10\% $\beta$-phase) obtained from Brazilian rives fish bones (Pintado - Pseudoplatystoma corruscans) in a recycling process. The bulk of PVDF polymer was formed in disk (thickness $1 \mathrm{~mm}$, diameter $10 \mathrm{~mm}$ ) by uniaxial pressure $(<50 \mathrm{MPa})$ and consolidated at $170{ }^{\circ} \mathrm{C}$ in air for 1 $\mathrm{h}$. Then, the BCP ceramic was achieved by $8 \mathrm{~h}$ of calcination at $900{ }^{\circ} \mathrm{C}$ and milled for $8 \mathrm{~h}$ at $300 \mathrm{rpm}$ in a mill (Retsh, PM 100) using a sphere/powder mass ratio of 6:1 [12]. The composite powder was homogenized (agate mortar, $30 \mathrm{~min}$ ), conformed in bars (thickness $1 \mathrm{~mm}$, width $5 \mathrm{~mm}$, length $10 \mathrm{~mm}$ ), discs (thickness $1.1 \mathrm{~mm}$, diameter 10 or $25 \mathrm{~mm}$ ) and cylinder (height $10 \mathrm{~mm}$, diameter $10 \mathrm{~mm}$ ) shapes (for different characterization protocols) and compacted under uniaxial pressure of $114 \mathrm{MPa}$. After that, the sample was consolidated at $170{ }^{\circ} \mathrm{C}$ in air for $1 \mathrm{~h}$.

Simulated body fluid (SBF), which simulates the conditions of the human body for preliminary bioactivity tests, in-vitro tests [35,36], was prepared in agreement with Kokubo protocol, or ISO 23317:2014, and used to investigate the bioactivity of the composite and its precursors. The samples' densities were obtained by the Archimedes method using distilled water. Structural characterizations were performed by X-ray diffraction (XRD) using a Shimadzu
XRD7000 diffractometer ( $\mathrm{CuK} \alpha$ radiation) in the $2 \theta$ range of $15^{\circ}$ to $50^{\circ}$ and a scan rate of $2 \%$ min. The samples' hardness was investigated by performing Vickers hardness $\left(\mathrm{H}_{\mathrm{v}}\right)$ tests (averaging 10 indentations on each sample) with an applied force of 204 gf in a Digital Multi Specimen Test System (UMT, CETR/Bruker) with a diamond indenter. Scanning electron microscopy (SEM) and energy dispersive spectroscopy (EDS) analyzes were performed in gold metalized samples by using an SEM-FEG HR (FEI, Inspect F50) microscope. The mechanical tests, performed to obtain the maximum compressive strength $(\sigma)$, were conducted in a Shimadzu universal mechanical testing machine AGS-X 100 $\mathrm{kN}$ according to the ASTM C773-88 [37]. The mechanical elastic coefficients [Young (E) and shear $(\mathrm{G})$ moduli] were obtained by using the impulse excitation technique (dynamic method) by following the ASTM E 1876 [38] in an ATCP Sonelastic tester. The Poisson's ratio ( $v$ ) was obtained using the following equation $[39,40]$ :

$$
v=\left(1-\frac{6 \mathrm{H}_{\mathrm{v}}}{\mathrm{E}}\right)\left(\frac{6 \mathrm{H}_{\mathrm{v}}}{\mathrm{E}}+2\right)^{-1}
$$

where $\mathrm{H}_{\mathrm{v}}$ is the measured Vickers hardness and E Young's modulus. The longitudinal modulus was obtained from:

$$
\mathrm{L}=\frac{2 \mathrm{G}(v-1)}{2 v-1}
$$

where $G$ is the shear modulus. The shear and longitudinal velocities of sound were given by:

$$
\begin{aligned}
& \mathrm{V}_{\mathrm{s}}=\left(\frac{\mathrm{G}}{\rho}\right)^{\frac{1}{2}} \\
& \mathrm{~V}_{\mathrm{L}}=\left(\frac{\mathrm{L}}{\rho}\right)^{\frac{1}{2}}
\end{aligned}
$$

Finally, the mean velocity of sound, or Debye mean velocity, was obtained from:

$$
\mathrm{V}_{\mathrm{M}}=\left[\frac{1}{3}\left(\frac{1}{\mathrm{~V}_{\mathrm{S}}{ }^{3}}+\frac{1}{\mathrm{~V}_{\mathrm{L}}{ }^{3}}\right)\right]^{-1 / 3}
$$

\section{RESULTS AND DISCUSSION}

Fig. 2 shows the XRD results for disk shape PVDF (polymer), BCP (ceramic), and PVDF-BCP (composite) samples. The XRD pattern of the PVDF sample (Fig. 2a) shows a typical amorphous pattern overlapped by two crystalline ones, which are associated to the nonpolar $(\alpha)$ and polar ( $\beta$ ) PVDF polymorphic phases. The XRD pattern obtained for the BCP ceramic (Fig. 2c) was perfectly indexed by overlapping the diffraction patterns of HA and $\beta$-TCP phases. The typical well-structured diffraction pattern of $\mathrm{BCP}$, overlapped with the amorphous PVDF signature, was observed in the XRD pattern of the PVDF-BCP composite (Fig. 2b). As expected, the well-crystallized BCP structure was predominant in this pattern due to the elevated X-ray 
scattering of $\mathrm{BCP}$ phase in comparison with that of the PVDF [41]. Furthermore, a line broadening was also observed in this pattern as an indicative of a well-homogenized mixture.

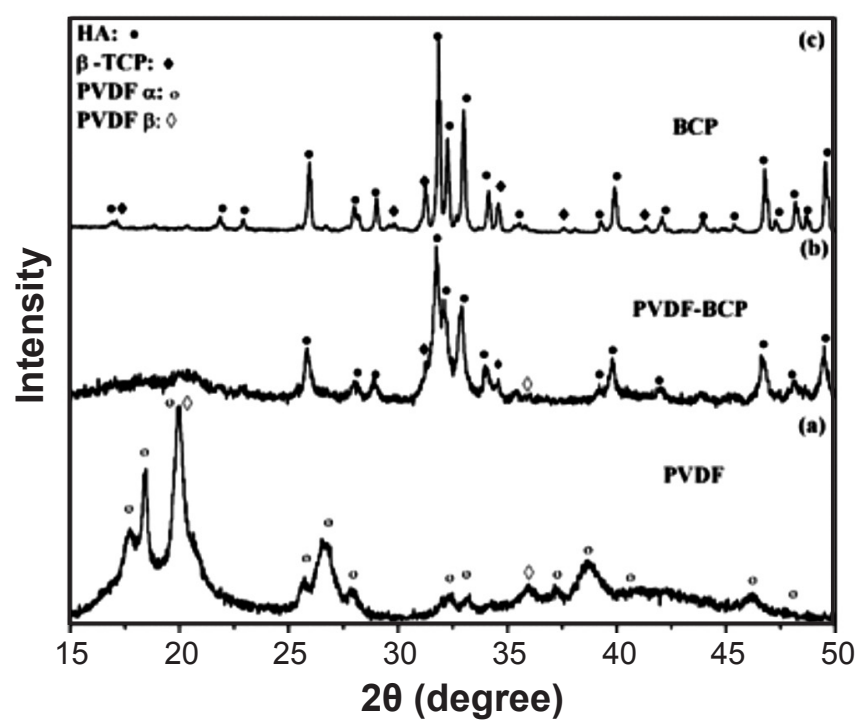

Figure 2: X-ray diffraction patterns for: (a) PVDF polymer; (b) PVDF-BCP composite; and (c) BCP ceramic, before immersion in simulated body fluid (SBF).

[Figura 2: Difratogramas de raios X para: (a) polímero PVDF; (b) compósito PVDF-BCP; e (c) cerâmica BCP, antes da imersão em fluido corporal simulado (SBF).]

Fig. 3 shows stress-strain curves, obtained from compressive mechanical tests, for the three studied samples (BCP, PVDF and PVDF-BCP) formed in a cylinder shape. As shown by the maximum loads ( $\operatorname{Load}_{\text {MAX }}$ ) highlighted in Fig. 3, the PVDF-BCP composite holds out higher mechanical stresses than PVDF or BCP samples. On the other hand, Young's modulus of the BCP phase, as expected for ceramics in comparison with polymer-ceramic composites, was higher than that obtained for the PVDF-BCP sample. However, a close look at the low load region revealed a very interesting behavior. As can be seen, in the very lowstress regime (inset in Fig. $3, \varepsilon<0.5 \%$ ) the drawn lines under the curves (solid, dashed and dotted) show considerable high inclinations in all cases. In fact, as high as the slope of stress $(\sigma)$-strain $(\varepsilon)$ curve $(\sigma=\mathrm{E} . \varepsilon)$ in the elastic region, higher is Young's modulus of the analyzed sample. In this way, it is seen that in the elastic regime the PVDF-BCP composite showed the highest Young's modulus and can be potentially used in implants where low compressive stress charges are required, as in bone grafts. However, with strain increasing $(\varepsilon<1.2 \%)$ the composite microstructure tended to accommodate the applied stress and an intermediate Young's modulus, between those observed for PVDF and BCP, was observed for the PVDF-BCP composite (Fig. 3).

The mechanical-elastic coefficients, total apparent densities and Vickers hardness obtained for PVDF polymer, BCP ceramic, and PVDF-BCP composite are listed in Table I. Previously reported mechanical coefficients for cortical and cancellous human bone tissue $[42,43]$ are also listed in

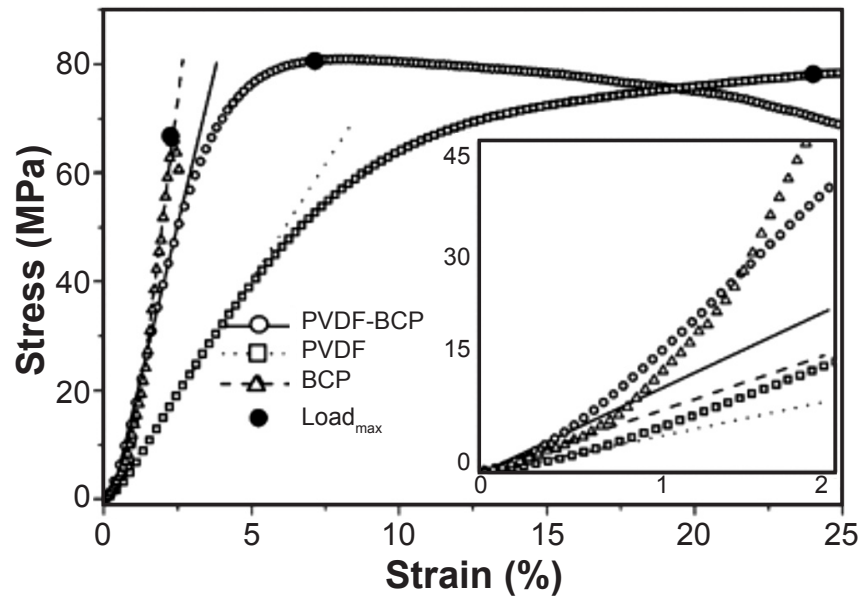

Figure 3: Compressive stress-strain curves for PVDF polymer, $\mathrm{BCP}$ ceramic, and PVDF-BCP composite. The draw lines are linear fit in elastic regions of the PVDF-BCP (solid line), BCP (dashed line) and PVDF (dotted line) compounds. Inset: enlarged view of the low strain region.

[Figura 3: Curvas tensão-deformação de compressão para o polímero $P V D F$, cerâmica BCP e compósito $P V D F-B C P$. As linhas foram ajustadas linearmente em regiões elásticas dos compostos PVDF-BCP (linha contínua), BCP (linha tracejada) e PVDF (linha pontilhada). Inserto: visão ampliada da região de baixa deformação.]

Table I for comparison. It is worth noting that the mechanical properties of human bone tissues are very dependent on the bone type, part of the body, age and even the sex of the specimen $[37,38]$. In addition, the osseous density of each individual animal body must be associated with personal characteristics (biotype, genetics, place and style of life, etc.) $[37,38]$. Likewise, the mechanical properties of the test-bodies are also dependent on their preparation, dry or wet bone, type of analysis, and others. Nevertheless, the obtained experimental data (Table I) can be used in our analyses as a base for comparison with those reported in the literature. The elastic moduli (Young and shear) of the PVDF-BCP composite reached intermediate values between PVDF and BCP. However, the Vickers hardness of the PVDF-BCP composite seemed to be closer to that of bone, both cortical and cancellous, than BCP ceramic. A significant result was also observed by comparing the densities of the studied samples. The composite density achieved an intermediate value $\left(2160 \mathrm{~kg} / \mathrm{m}^{3}\right)$ between cortical bone $\left(1810 \mathrm{~kg} / \mathrm{m}^{3}\right)$ and porous $\mathrm{BCP}$ ceramic $\left(2360 \mathrm{~kg} / \mathrm{m}^{3}\right)$ that is closer to the human bone than BCP, even more if this result is compared with that reported for non-porous HA $\left(3156 \mathrm{~kg} / \mathrm{m}^{3}\right)$ [44]. The shear modulus of the composite was also more similar to that of bone than that observed for PVDF or BCP, as shown in Table I. On the other side, the Poisson's ratio of the PVDF-BCP composite was very similar to that of bone and BCP. The maximum compressive strength reached by the composite $(\sim 80 \mathrm{MPa})$ was the greatest among those investigated samples and was close to the observed for human femur (107 MPa) [44]. Finally, the sound velocities were also calculated and showed to be proportional to the respective 
Table I - Mechanical properties for PVDF polymer, BCP ceramic, PVDF-BCP composite, cortical and cancellous human bone tissues: Vickers hardness $\left(\mathrm{H}_{\mathrm{v}}\right)$, Young's or elastic modulus $(\mathrm{E})$, shear modulus $(\mathrm{G})$, maximum compressive strength $(\sigma)$, Poisson's ratio $(v)$, density $(\mathrm{Q})$, and shear $\left(\mathrm{V}_{\mathrm{S}}\right)$, longitudinal $\left(\mathrm{V}_{\mathrm{L}}\right)$, and mean $\left(\mathrm{V}_{\mathrm{M}}\right)$ velocities of sound in the medium.

[Tabela I - Propriedades mecânicas para polímero PVDF, cerâmica BCP, compósito PVDF-BCP, tecido cortical e tecido esponjoso dos ossos humanos: dureza Vickers $\left(H_{V}\right)$, módulo de Young ou elástico $(E)$, módulo de cisalhamento $(G)$, resistência de compressão máxima $(\sigma)$, razão de Poisson $(v)$, densidade $(\varrho)$ e velocidades de cisalhamento $\left(V_{S}\right)$, longitudinal $\left(V_{L}\right) e$ média $\left(V_{M}\right)$ do som no meio.]

\begin{tabular}{|c|c|c|c|c|c|c|c|c|c|}
\hline Compound & $\begin{array}{c}\mathrm{H}_{\mathrm{v}} \\
(\mathrm{GPa})\end{array}$ & $\begin{array}{c}\mathrm{E} \\
(\mathrm{GPa})\end{array}$ & $\begin{array}{c}\mathrm{G} \\
(\mathrm{GPa})\end{array}$ & $\begin{array}{c}\sigma \\
(\mathrm{MPa})\end{array}$ & $v$ & $\underset{\left(\mathrm{kg} / \mathrm{m}^{3}\right)}{\varrho}$ & $\begin{array}{c}\mathrm{V}_{\mathrm{S}} \\
(\mathrm{m} / \mathrm{s})\end{array}$ & $\begin{array}{c}\mathrm{V}_{\mathrm{L}} \\
(\mathrm{m} / \mathrm{s})\end{array}$ & $\begin{array}{c}\mathrm{V}_{\mathrm{M}} \\
(\mathrm{m} / \mathrm{s})\end{array}$ \\
\hline $100 \% \mathrm{PVDF}$ & $0.211 \pm 0.005$ & $1.34 \pm 0.12$ & $0.59 \pm 0.02$ & $77.5 \pm 1.7$ & 0.02 & 1698 & 623 & 891 & 815 \\
\hline PVDF-BCP & $0.212 \pm 0.007$ & $4.55 \pm 0.50$ & $1.97 \pm 0.07$ & $80.4 \pm 0.8$ & 0.31 & 2160 & 891 & 1713 & 1230 \\
\hline $100 \% \mathrm{BCP}$ & $1.148 \pm 0.050$ & $26.01 \pm 3.01$ & $11.35 \pm 0.46$ & $66.6 \pm 0.5$ & 0.33 & 2360 & 2066 & 4090 & 2861 \\
\hline Cortical tissue & $0.59 \pm 0.200[37]$ & $18.30 \pm 3.50[37]$ & $3.30 \pm 0.50[37]$ & $107 \pm 4.3[38]$ & 0.37 & 1810 [38] & 1922 & 4203 & 2689 \\
\hline Cancellous tissue & $0.52 \pm 0.150[37]$ & $13.00 \pm 1.47[37]$ & -- & -- & 0.34 & $1100[38]$ & 2100 & 4258 & 2917 \\
\hline
\end{tabular}

elastic modulus and Vickers hardness, as expected. As observed by comparatively analyzing the mechanical properties of PVDF-BCP composite, its huge potential for multifunctional applications in bone implants become evident.

Fig. 4 shows the FEG-SEM images and the EDS analysis performed on the surfaces and fractured surfaces of BCP, PVDF and PVDF-BCP disk shape samples recovered from immersion in simulated body fluid (SBF) for 7 days. These tests in SBF can reveal the bioactivity of material by the direct observation (preferentially by SEM) of an HA layer formed on the surface/pores of the analyzed sample, as well as by the determination of the dimensions of this layer. In this way, as high the material bioactivity, higher is the HA layer observed in the SEM analysis. As can be seen, the apatite layer on the surface of BCP ceramic reached a thickness of $\sim 3 \mu \mathrm{m}$ (Fig. 4a), attesting its elevated bioactivity. Images of fractured surfaces were also obtained for helping understand the growth paths of HA in this sample. The SEM analysis of fractured surfaces of the BCP sample ceramic revealed a high porous sample with an HA layer grown inside the pores (Fig. 4d). This result is in agreement with previous works on modified BCP ceramics, where an HA layer was also observed inside the ceramics' pores [45]. In fact, in most cases, the intra-porous growth is desired because it can create a more interconnected structure that can help in the healing process by changing its kinetics in a faster osteointegration [5]. Interestingly, a still larger HA layer was observed on the surface of the PVDF-BCP composite, reaching a thickness of $\sim 9 \mu \mathrm{m}$, which was 3 times higher than that observed in the $\mathrm{BCP}$ ceramic. This may be due to porosity difference and/or the biocompatibility itself. In fact, usually BCP ceramics are more porous and because this the apatite formation can occur into the pores. Furthermore, spheres with $\sim 10 \mu \mathrm{m}$ in diameter can be observed on the surface of the PVDFBCP composite (Fig. 4b) in a clear evidence of a uniform HA formation [46]. Differently, the SEM analysis of the fractured PVDF-BCP surface (Fig. 4e) did not reveal pores filled by HA. It is worth noting that in many cases, such as cartilaginous tissue of the ear or the confection of a mesh to support broken tissues, surface growth can be most desired to maintain the flexibility of this kind of tissue. Thus, it is clear that the PVDF-BCP composite can be potentially used in such kind of application. Moreover, techniques for obtaining controlled scaffolds can be used to produce pores in the PVDF-BCP composite, increasing its range of medical and biological applicability. Conversely, an HA layer was not observed in the PVDF polymer (Fig. 4c). In fact, a high dense and high compressed polymer matrix was observed in the SEM analysis of the PVDF fractured surface (Fig. 4f). It is worth noting that the EDS analyzes showed different surface compositions for the three studied samples (Figs. 4g to 4i). In fact, the EDS analysis shown in Fig. $4 \mathrm{~g}$ reveals the presence of $\mathrm{Ca}$ and $\mathrm{P}$ ions on the surface of the BCP ceramic, indicating this phase as a typical HA layer. Likewise, EDS results (Fig. 4h) confirmed the HA type growth on the surface of the PVDF-BCP composite. Besides, the F EDS peak [characteristic of PVDF $\left(\mathrm{C}_{2} \mathrm{H}_{2} \mathrm{~F}_{2}\right)_{\mathrm{n}}$ ] observed in the apparent layer grown on the surface of the PVDF polymer (Fig. 4c) indicated that it was only a piece of the own polymer that had broken in the grinding process used before the SBF immersion. Unfortunately, the overlap of EDS peaks originating from $\mathrm{Au}$ and $\mathrm{P}$ ions prevents the establishment of the atomic percentage of $\mathrm{Ca}$ and $\mathrm{P}$, which help to specify the type of HA grown on the PVDF-BCP composite.

In summary, a PVDF-BCP biocomposite, with elevated bioactivity and mechanical properties close to that of human bone tissue (both cortical and cancellous), was successfully obtained and characterized. The young osseous structural characteristics of the PVDF-BCP composite indicated its great potential for practical applications because this type of bone is highly bioactive. Furthermore, the overlapping with PVDF polymorphic phases can add multifunctional characteristics to this composite [30]. In addition, different thermal and mechanical properties of the BCP ceramic and PVDF polymer can be tuned to obtain a biocomposite 



Figure 4: SEM images of surfaces profile (top), fractured surfaces (middle), and EDS spectra of the surfaces for: (a,d,g) BCP ceramic; (b,e,h) PVDF-BCP composite; and (c,f,i) PVDF polymer.

[Figura 4: Micrografias obtidas por microscopia eletrônica de varredura do perfil de superfícies, das superfícies de fratura e espectros de EDS das superfícies de: $(a, d, g)$ cerâmica BCP; $(b, e, h)$ compósito PVDF-BCP; e $(c, f, i)$ polímero PVDF.]

with a wide range of properties. In this way, the PVDF$\mathrm{BCP}$ biocomposite can be potentially applied as an osseous implant in different parts of the animal/human body. The potential to explore the piezoelectric properties of the PVDF matrix on the PVDF-BCP composite, focusing to activate and change the kinetics of the healing process in the implanted prosthesis, can expand the multifunctional characteristics of this composite [30]. In fact, these properties can be used in the future to activate the healing process by promoting the ion exchange on the surfaces of the bioactive material [47]. This methodology can be employed in future physiotherapeutic treatments to accelerate the complete restoration of damaged bone tissues. Finally, and considering the possibilities for the improvement of the thermal, piezoelectric and mechanical properties, as well as the biocompatible characteristics and even that the structure of the PVDF-BCP composite is very similar to that of the highly regenerating young bone, it is plausible to intuit the possibilities for multifunctional practical applications for these composites.

\section{CONCLUSIONS}

Abioactive PVDF-BCP composite was synthesized and its structural microstructural and mechanical properties, as well as its bioactivity, were studied. The PVDF-BCP composite proved to be a highly bioactive material because a thick apatite layer $(\sim 9 \mu \mathrm{m})$ was observed on its surface after just 7 days under immersion in simulated body fluid. Mechanical tests revealed a strong composite with properties similar to the human bone, with a strength reaching $80 \mathrm{MPa}$. In fact, piezoelectrically bioactive PVDF-BCP composites can be potentially used in the future physiotherapeutic process, in which electric field would be used to reorganize electric ions on the bioactive surface of the composite and accelerate the healing process. Nevertheless, the wide range of properties that are possible to be obtained in this family of materials enhances their use in osseous implants for different parts of the animal/human body. 


\section{ACKNOWLEDGEMENTS}

The authors would like to thank the Brazilian agencies CNPq (proc. 474554/2013-9, 308622/2013-8 and 446565/2014-8), CAPES (PVE 88881.030465/201301, PROCAD 88881.068509/2014-01) and Fundação ARAUCÁRIA de Apoio ao Desenvolvimento Cientifico e Tecnológico do Paraná for financial support. Special thanks to LME/LNNano/CNPEM (Campinas-Brazil) for the technical assistance for the electron microscopy work.

\section{REFERENCES}

[1] B.D. Ratner, A.S. Hoffman, F.J. Schoen, J.E. Lemons, Biomaterials science: an introduction to materials in medicine, Academy Press, New York (1996).

[2] A.P.V. Pereira, W.L. Vasconcelos, R.L. Oréfice, Polímeros 9 (1999) 104.

[3] M.I. Kay, R.A. Young, A.S. Posner, Nature 204 (1964) 1050.

[4] R.L. Oréfice, Biomateriais: fundamentos e aplicações, Cultura Médica, Rio de Janeiro (2006).

[5] S. Pollick, E.C. Shors, R.E. Holmes, R.A. Kraut, J. Oral Maxillofac. Surg. 53 (1995) 915.

[6] I. Ono, T. Tateshita, T. Nakajima, Biomaterials 21 (2000) 143.

[7] R.Z. Legeros, Clin. Orthop. Relat. Res. 395 (2002) 81.

[8] P. Li, K.D.E. Groot, T. Kokubo, J. Sol-Gel Sci. Technol. 7 (1996) 27.

[9] W. Cao, L.L. Hench, Ceram. Int. 22 (1996) 493.

[10] N. Specchia, A. Pagnotta, M. Cappella, A. Tampieri, F. Greco, J. Mater. Sci. 37 (2002) 577.

[11] J. Venugopal, P. Vadgama, T.S.S. Kumar, S. Ramakrishna, Nanotechnology 18 (2007) 1.

[12] T.M. Coelho, E.S. Nogueira, A. Steimacher, A.N. Medina, W.R. Weinand, W.M. Lima, M.L. Baesso, A.C. Bento, J. Appl. Phys. 100 (2006) 094312.

[13] C. Gao, B. Yang, H. Hu, J. Liu, C. Shuai, S. Peng, Mater. Sci. Eng. C 33 (2013) 3802.

[14] Y. Tanimoto, Y. Shibata, A. Murakami, T. Miyazaki, N. Nishiyama, J. Hard Tissue Biol. 18 (2009) 2.

[15] S. Raynaud, E. Champion, J.P. Lafon, D. BernacheAssollant, Biomaterials 23 (2002) 1081.

[16] M. Kohri, K. Miki, D.E. Waite, H. Nakajima, T. Okabe, Biomaterials 14 (1993) 299.

[17] A.D.B.L. Ferreira, P.R.O. Nóvoa, A.T. Marques, Compos. Struct. 151 (2016) 3.

[18] T.G.M. Bonadio, V.F. Freitas, T.T. Tominaga, R.Y. Miyahara, J.M. Rosso, L.F. Cótica, M.L. Baesso, W.R. Weinand, I.A. Santos, R. Guo, A.S. Bhalla, Curr. Appl. Phys. 17 (2017) 767.

[19] F.R. Baxter, C.R. Bowen, I.G. Turner, A.C.E. Dent, Ann. Biomed. Eng. 38 (2010) 2079.

[20] K. Yamashita, N. Oikawa, T. Umegaki, Chem. Mater. 8 (1996) 2697.

[21] K.S. Hwang, J.E. Song, J.W. Jo, H.S. Yang, Y.J. Park, J.L. Ong, H.R. Hawls, J. Mater. Sci. Med. 13 (2002) 133.
[22] M.P. Mahabole, R.C. Aiyer, C.R. Ramakrishna, B. Sheedhar, R.S. Khairnar, Bull. Mater. Sci. 28 (2005) 535.

[23] J. Feng, H.P. Yuan, X.D. Zhang, Biomaterials 18 (1997) 1531.

[24] M.M. Beloti, P.T. Oliveira, R. Gimenes, M.A. Zaghete, M.J. Bertolini, A.L. Rosa, J. Biomed. Mater. Res. 79 (2006) 282.

[25] J.E. Davies, Surface characterization of biomaterials, Elsevier, Amsterdam (1988).

[26] D.M. Correia, R. Gonçalves, C. Ribeiro, V. Sencadas, G. Botelho, J.L.G. Ribelles, S.L. Mendez, RSC Adv. 4 (2014) 33013.

[27] D.M. Correia, C. Ribeiro, V. Sencadas, L. Vikingsson, M.O. Gasch, J.L.G. Ribelles, G. Botelho, S.L. Mendez, Colloids Surf. B Biointerfaces 140 (2016) 430.

[28] C. Ribeiro, S. Moreira, V. Correia, V. Sencadas, J.G. Rocha, F.M. Gama, J.L.G. Ribelles, S.L. Mendez, RSC Adv. 2 (2012) 11504.

[29] J. Parssinen, H. Hammaren, R. Rahikainen, V. Sencadas, C. Ribeiro, S. Vanhatupa, S. Miettinen, S.L. Mendez, V.P. hytonen, J. Biomed. Mater. Res. A 103 (2015) 919.

[30] C. Ribeiro, J. Parssinen, V. Sencadas, V. Correia, S. Miettinen, V.P. Hytonen, S.L. Mendez, J. Biomed. Mater. Res. A 103 (2015) 2172.

[31] Y. Yu, H. Sun, H. Orbay, F. Chen, C.G. England, W. Cai, X. Wang, Nano Energy 27 (2016) 275.

[32] A.A. Ribeiro, L.G. Vaz, A.C. Guastaldi, J.S.C. Campos, Appl. Surf. Sci. 258 (2012) 10110.

[33] H. Kawaii, Jap. J. Appl. Phys. 8 (1969) 975.

[34] C. Constantino, A. Job, R. Simões, J. Giacometti, V. Zucolotto, O. Oliveira, J. Gozzi, D. Chinaglia, Appl. Spectrosc. 59 (2005) 275.

[35] H.M. Kim, F. Miyaji, T. Kokubo, C. Ohtsuki, T. Nakamura, J. Am. Ceram. Soc. 78 (1995) 2405.

[36] Y. Abe, M. Kawashita, T. Kokubo, T. Nakamura, J. Ceram. Soc. Jpn. 109 (2001) 106.

[37] Am. Soc. Test. Mater., ASTM C773-88: "Standard test method for compressive (crushing) strength of fired whiteware materials", B. Stand. (2011).

[38] Am. Soc. Test. Mater., ASTM E1876-09: "Standard test method for dynamic Young's modulus, shear modulus, and Poisson's ratio by impulse excitation of vibration", B. Stand. (2012).

[39] E.S.S. Yousef, J. Phys. D Appl. Phys. 38 (2005) 3970. [40] J.A. Sampaio, M.L. Baesso, S. Gama, A.A. Coelho, J.A. Eiras, I.A. Santos, J. Non-Cryst. Solids 304 (2002) 293. [41] T.H. Lee, F.Y.C. Boey, K.A. Khor, Polym. Compos. 16 (1995) 481-488.

[42] S.C. Cowin, Bone mechanics handbook, $2^{\text {nd }}$ Ed., CRC Press, New York (2001).

[43] S. Pal, Design of artificial human joints \& organs, Spring, New York (2014).

[44] W.R. Weinand, A.C. Bento, M.L. Baesso, W.M. Lima, J. Appl. Phys. 104 (2008) 2.

[45] G. Ciobanua, S. Ilisei, C. Lucaa, G. Carjaa, O. Ciobanub, Prog. Org. Coat. 74 (2012) 648.

[46] A. Takeuchi, C. Ohtsuki, T. Miyazaki, M. Kamitakahara, 
S.-I. Ogata, M. Yamazaki, Y. Furutani, H. Kinoshita, M. Tanihara, J. R. Soc. Interface 2 (2005) 373.
[47] H.S. Nalwa, Ed., Ferroelectric polymer: chemistry, physics and applications, Hitachi, lbaraki (1995).

(Rec. 21/07/2017, Rev. 29/12/2017, Ac. 14/01/2018) 